\title{
Inhibition of magnesium corrosion by triazoles
}

\author{
Yu.I. Kuznetsov, A.M. Semiletov and A.A. Chirkunov \\ A.N. Frumkin Institute of Physical Chemistry and Electrochemistry, Russian Academy \\ of Sciences, Leninskii pr. 31, Moscow, 119071 Russian Federation \\ E-mail: kuznetsov@ipc.rssi.ru
}

\begin{abstract}
The inhibitive action of some azoles (1,2,4-triazole, 1,2,3-benzotriazole, 5-chlorobenzotriazole, and IFKhAN-92 corrosion inhibitor) on the corrosion of magnesium was investigated in aqueous buffer solutions and humid atmosphere. Increasing the hydrophobicity and decreasing the $\mathrm{p} K_{\mathrm{a}}$ of $\mathrm{NH}$-acids enhance the protection of $\mathrm{Mg}$ by triazoles, that is why 5-chlorobenzotriazole and IFKhAN-92 - a mixture of substituted triazoles - are more efficient inhibitors. Small additions of dioctylphosphate increase the protection of $\mathrm{Mg}$ in aqueous solution by IFKhAN-92 inhibitor, and addition of trialkoxysilane to the mixed inhibitor allows one to enhance the protection of $\mathrm{Mg}$ in a humid atmosphere.
\end{abstract}

Keywords: magnesium, corrosion, corrosion inhibitors, triazoles.

Received: October 1, 2015. Published: December 27, 2015.

doi: $\underline{10.17675 / 2305-6894-2016-5-1-3}$

\section{Introduction}

Due to the increase in the interest in Mg alloys not only in aerospace but also in many other industries in the past decades, protection of these alloys from corrosion deserves special attention. It is well known that while $\mathrm{Mg}$ alloys have many technological advantages over other alloys, including very low specific density, high specific strength and heat capacity, as well as excellent machinability, they are markedly inferior to aluminum alloys in corrosion resistance, especially in chloride-containing environments. The standard electrode potential of magnesium is $E_{\mathrm{Mg} / \mathrm{Mg}^{2+}}^{0}=-2.37 \mathrm{~V}$, which itself already indicates its high thermodynamic tendency to oxidation and corrosion. For this reason, it becomes the anode even in contact with $\mathrm{Al}$ and $\mathrm{Zn}$, not to mention the less electronegative metals. Not surprisingly, the corrosion rate of technical $\mathrm{Mg}(99.9 \%)$ is hundreds of times larger than that of the high purity metal (99.99\%) due to harmful effects of $\mathrm{Fe}, \mathrm{Ni}$ and $\mathrm{Cu}$ impurities [1]. The corrosion rate of $\mathrm{Mg}$ in wet but clean atmosphere is low due to a protective layer of its hydroxide formed by slow hydration of magnesium oxide [2].

The traditional methods of $\mathrm{Mg}$ alloy corrosion protection (chromate treatment and paint coatings containing chromate pigments or inhibitors) have been facing serious environmental objections in recent years. Furthermore, even chromate conversion coatings (CC) on technical $\mathrm{Mg}$ and alloys do not provide long term protection, especially in industrial atmosphere, where corrosion, e.g., on passivated ML 5 alloy, already appears 
after 20 days. In this regard, development of efficient protective means for $\mathrm{Mg}$ and its alloys is particularly relevant.

Attempts to create a protective film on $\mathrm{Mg}$ and its alloys by phosphate treatment, including electrochemical methods, were made a long time ago [3]. However, little success was achieved, despite the fact that $\mathrm{Mg}$ underwent phosphatizing more easily than Al. In some cases it was possible to obtain conversion coatings with a better protective effect than after $\mathrm{Mg}$ treatment with selenious acid or HF, however, according to M.A. Timonova, they failed to surpass the films obtained by chromate treatment.

As early as in 1910, V.A. Kistyakovsky observed $\mathrm{Mg}$ passivation in alkaline solutions, and later it was found [4] that its corrosion rate decreased with increasing $\mathrm{pH}$ and corrosion nearly ceased at $\mathrm{pH} 11-12$. However, in alkaline media, small additions of chloride, sometimes a few $\mathrm{mg} / \mathrm{l}$, can disrupt the passive state of alloys.

Some of oxide coatings obtained on $\mathrm{Mg}$ alloys by various methods are formed in chromate-free solutions. It is essential that despite the variety of protection methods, the most attention of researchers, according to patent literature [5], belongs to CC (41\% of all patented technologies). This is due to their excellent adhesion to the metal substrate and low cost. A detailed review of these methods is given in [5-8]. Besides the already noted type of CC obtained in phosphating compositions that contain not only cations of various metals but also phosphonate corrosion inhibitors, attempts to obtain $\mathrm{CC}$ in molybdate, vanadate, and tartrate solutions should be noted. The use of silanes in this process is noteworthy. According to [9], addition of a silane to a vanadate solution increased not only the adhesion of the paint to the $\mathrm{CC}$, but also protection against corrosion in a $5 \%$ salt fog chamber.

Development of electrochemical anodizing of $\mathrm{Mg}$ alloys as a method for application of functional and protective coatings also continued in recent years. For example, plasma electrolytic oxidation (PEO) makes it possible to obtain thicker coatings on $\mathrm{Mg}$ alloys. Addition of $\mathrm{TiO}_{2}$ nanoparticles to the electrolyte or filling the coating with tetrafluoropolyethylene enhances its protective properties and can improve its durability and provide super-hydrophobization of the surface [6].

However, many protective coatings suffer from the same drawback: they have defects (cracks, pores, etc.) which are not only present inherently, but also appear in time upon exposure to the environment or upon destruction of the coating. The problem of "selfhealing" of protective coatings for $\mathrm{Mg}$ alloys, as well as other metals, is very serious if chromates are no longer used. As correctly observed in [10], it can be solved by incorporation of $\mathrm{Mg}$ corrosion inhibitors into the coating, and the most efficient ones should be selected for this purpose.

It is easy to notice that success in the application of chromate inhibitors discouraged for a long time the interest in other corrosion inhibitors for $\mathrm{Mg}$. Recently, it was noted that corrosion inhibitors of $\mathrm{Mg}$ alloys undeservedly received little attention [11,12]. A good overview of studies on this subject is given in the article by Frignani et al. [12]. Apparently, sodium dodecylbenzenesulfonate is the best-studied nontoxic organic 
corrosion inhibitor for $\mathrm{Mg}$. It is not only very efficient in the protection of $\mathrm{Mg}$ alloys, but also demonstrates synergy in protection of AZ91D alloy with 8-hydroxyquinoline [13], which is known for its ability to form sparingly soluble complexes with $\mathrm{Mg}^{2+}$ [14].

It is known that organic inhibitors are able to create thin or even ultrathin protective coatings on a metal from aqueous solutions [15-17]. Unfortunately, almost no systematic studies of organic inhibitors and creation of nano-sized and thin $(\leq 2 \mu \mathrm{m})$ coatings on $\mathrm{Mg}$ on their basis have been carried out. Therefore, this paper presents some new options for the protection of technical $\mathrm{Mg}$ in aqueous solutions by compounds of triazole class that are often efficient corrosion inhibitors for ferrous and non-ferrous metals $[17,18]$.

\section{Experimental}

Corrosion and electrochemical tests were conducted using samples of technical $\mathrm{Mg}$ ( $\mathrm{Mg}$ 90) with the composition: $\mathrm{Mg}-99.9 \%, \mathrm{Fe}-$ up to $0.04 \%, \mathrm{Mn}-$ up to $0.03 \%, \mathrm{Al}-$ up to $0.02 \%, \mathrm{Ni}$ - up to $0.001 \%, \mathrm{Cu}-$ up to $0.004 \%, \mathrm{Si}-$ up to $0.009 \%, \mathrm{Cl}-$ up to $0.005 \%$. Electrochemical measurements were carried out using cylindrical electrodes with a working surface area of $0.72 \mathrm{~cm}^{2}$ mounted in epoxy resin. Borate buffer solution with $\mathrm{pH}$ 7.36 was mainly used as the background solution, but borate solution with $\mathrm{pH} 9.2$ was also used in some experiments. Polarization curves of $\mathrm{Mg}$ were recorded in a glass cell with separate electrode spaces using a PI 50-1.1 potentiostat. Potentials $(E)$ of $\mathrm{Mg}$ were measured relative to a silver chloride electrode and converted to the normal hydrogen scale. A platinum auxiliary electrode was used. Before experiments, the electrodes were polished and degreased with acetone.

1,2,4-Triazole (TA), 1,2,3-benzotriazole (BTA), 5-chloro-benzotriazole (Cl-BTA), and IFKhAN-92 inhibitor ware studied as Mg corrosion inhibitors. Working solutions were prepared by dissolving a triazole in water (TA, BTA) or in isopranol (Cl-BTA, IFKhAN92) with continuous stirring for $30 \mathrm{~min}$.

A triazole solution to be tested was introduced into the electrochemical cell, then the magnesium electrode was immersed into it. The electrode was kept for 15 minutes to establish the free corrosion potential $E_{\mathrm{c}}$, then anodic polarization curves were recorded in potentiodynamic mode with a potential sweep rate of $0.2 \mathrm{mV} / \mathrm{s}$.

Corrosion tests in borate solutions with $\mathrm{pH} 7.36$ and 9.20 were carried out with $\mathrm{Mg}$ 90 samples sized $3.3 \times 2 \times 0.5 \mathrm{~cm}$. The exposure duration of samples in solution ranged from 0.5 to 12 hours. Corrosion products were removed from the surface of magnesium samples by keeping them for 30 seconds in an aqueous solution containing $60 \mathrm{~g} \mathrm{~L}^{-1}$ potassium dichromate acidified with sulfuric acid to $\mathrm{pH}$ 1.0-1.4. Generally, three samples were tested in parallel per data point; the relative measurement error did not exceed $5-7 \%$. The corrosion rate of $\mathrm{Mg}$ was calculated by the formula:

$$
K\left[\mathrm{~g} \cdot\left(\mathrm{m}^{2} \cdot \mathrm{h}\right)^{-1}\right]=\Delta m / S \cdot t,
$$


where $S$ is the sample surface area $\left[\mathrm{m}^{2}\right] ; t$ is the test duration [h]. The value of $\Delta m$ included the correction for the loss of mass of the blank sample exposed to similar etching treatment $\left[0.03 \mathrm{mg} / \mathrm{cm}^{2}\right]$.

The passivating effect of inhibitors was also estimated from the results of corrosion tests of $\mathrm{Mg}$ plates in a heat-and-moisture cabinet after immersing them for 10 minutes in distilled water containing $5 \mathrm{mM}$ of the inhibitor being tested at $t=20$ and $60^{\circ} \mathrm{C}$. In some cases, passivation was achieved with stirring the solution on a magnetic stirrer at a speed of $V \sim 0.3 \mathrm{~m} / \mathrm{s}$. The time until the first corrosion damage on the samples served as the criterion of passivation efficiency. The cabinet operated in the mode: $t=40^{\circ} \mathrm{C}$ for $8 \mathrm{~h}$ and no heating for the rest of the day, which resulted in abundant condensation on the samples.

\section{Results and discussion}

As noted above, chromate is the most studied and very efficient corrosion inhibitor of $\mathrm{Mg}$ and its alloys. However, its toxicity and hazard to the environment makes it necessary to replace chromate in various technologies. Sodium molybdate is most similar to it in chemical properties. It has low toxicity and is often suggested as a substitute for chromate [19].

As one can see from the time-potential curves shown in Figure 1, the starting electrode potential of $\mathrm{Mg}\left(E_{\mathrm{s}}\right)$ upon immersion in borate buffer $(\mathrm{pH}$ 7.4) containing no chlorides is very negative, $E_{\mathrm{s}}=-1.68 \mathrm{~V}$, but increases with time. This is due to the formation of an oxide-hydroxide layer accompanied by evolution of hydrogen at the electrode, which slows down with time. The $E_{\mathrm{s}}$ value is established in 3 hours and reaches $-1.4 \mathrm{~V}$. In solutions containing potassium dichromate, $E_{\mathrm{s}}$ is considerably less negative, which is particularly noticeable at a higher concentration $(C=10 \mathrm{mmol} / \mathrm{l})$ and the final potential $\left(E_{\mathrm{f}}\right)$ is attained more quickly. Its value in a dilute dichromate solution is even slightly more negative than in the background solution. However, in $10 \mathrm{mmol} / 1 \mathrm{~K}_{2} \mathrm{Cr}_{2} \mathrm{O}_{7}$ solution, not only $E_{\mathrm{s}}$ but $E_{\mathrm{f}}$ are hundreds of millivolts more positive than the similar values for $\mathrm{Mg}$ in pure borate buffer. This is because, as an oxidant, dichromate can undergo reduction on magnesium surface to form thereon a protective film containing hardly soluble compounds, for example $\mathrm{Cr}_{2} \mathrm{O}_{3}$, which results in inhibition of both electrode reactions and metal passivation.

Indeed, if follows from the analysis of polarization curves on $\mathrm{Mg}$ (Figure 2a) that even at $C=1 \mathrm{mmol} / 1$ dichromate increases significantly the cathodic polarization of the electrode, although its effect on the anodic dissolution of the metal, at least up to $i_{\text {an }} \leq$ $40 \mathrm{~mA} / \mathrm{cm}^{2}$, is rather small. Increasing $C$ to $5 \mathrm{mmol} / \mathrm{l}$, and especially to $10 \mathrm{mmol} / \mathrm{l}$ $\mathrm{K}_{2} \mathrm{Cr}_{2} \mathrm{O}_{7}$, leaves no doubt as to the passivating ability of chromate, as well as improving to the efficiency of its inhibitive effect on the cathodic reaction on $\mathrm{Mg}$ as well. 

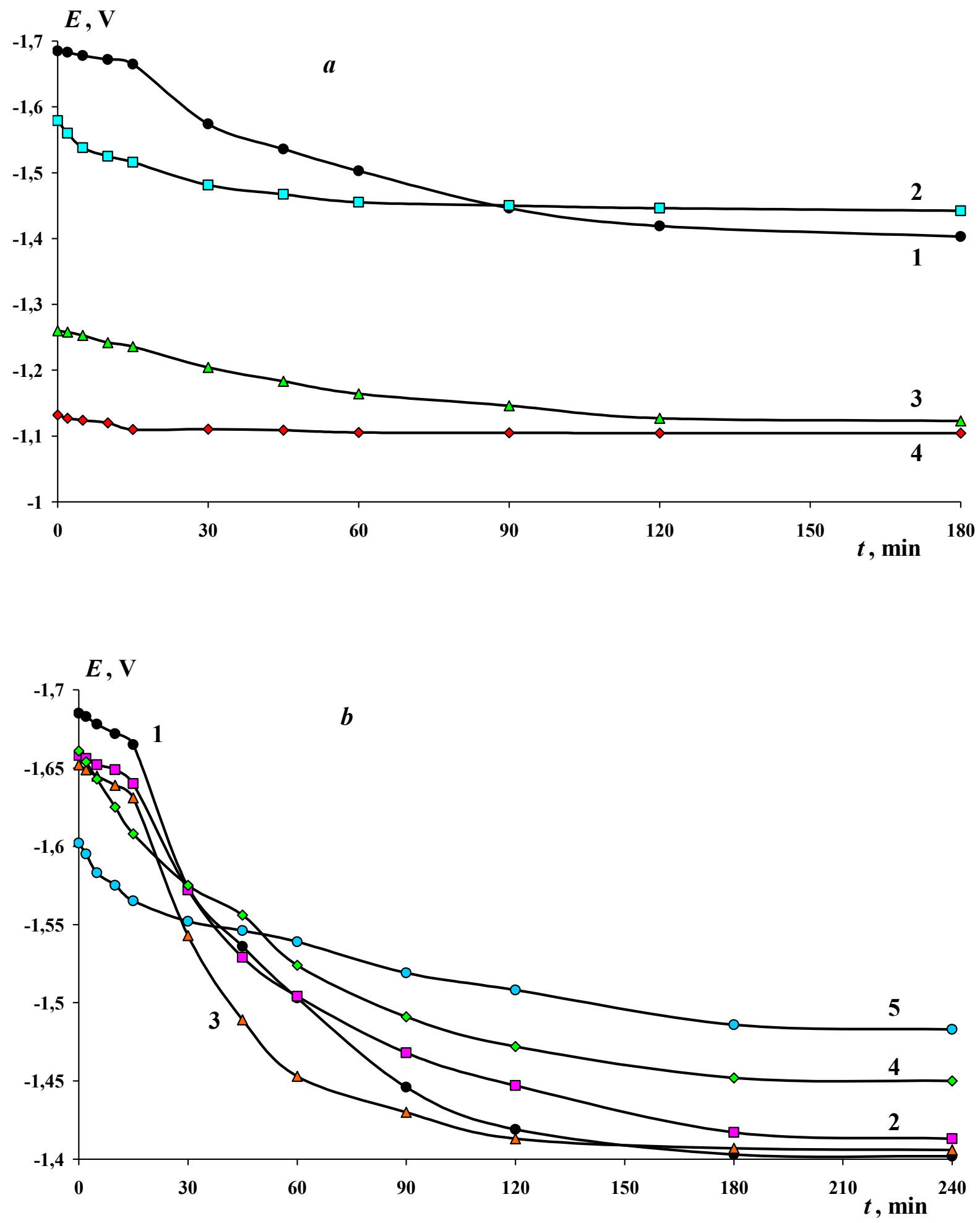

Figure 1. Variation in electrode potential of magnesium in borate buffer with $\mathrm{pH} 7.4$ without (1) and with addition of $a$ ) potassium dichromate $\left(2-1.0,3-10 \mathrm{mmol} \cdot \mathrm{L}^{-1}\right)$; sodium molybdate $\left.\left(4-10 \mathrm{mmol} \cdot \mathrm{L}^{-1}\right) ; b\right) 10 \mathrm{mmol} \cdot \mathrm{L}^{-1}$ of triazoles $(2-\mathrm{TA} ; 3-\mathrm{BTA} ; 4-\mathrm{Cl}-\mathrm{BTA} ; 5$ IFKhAN-92. 

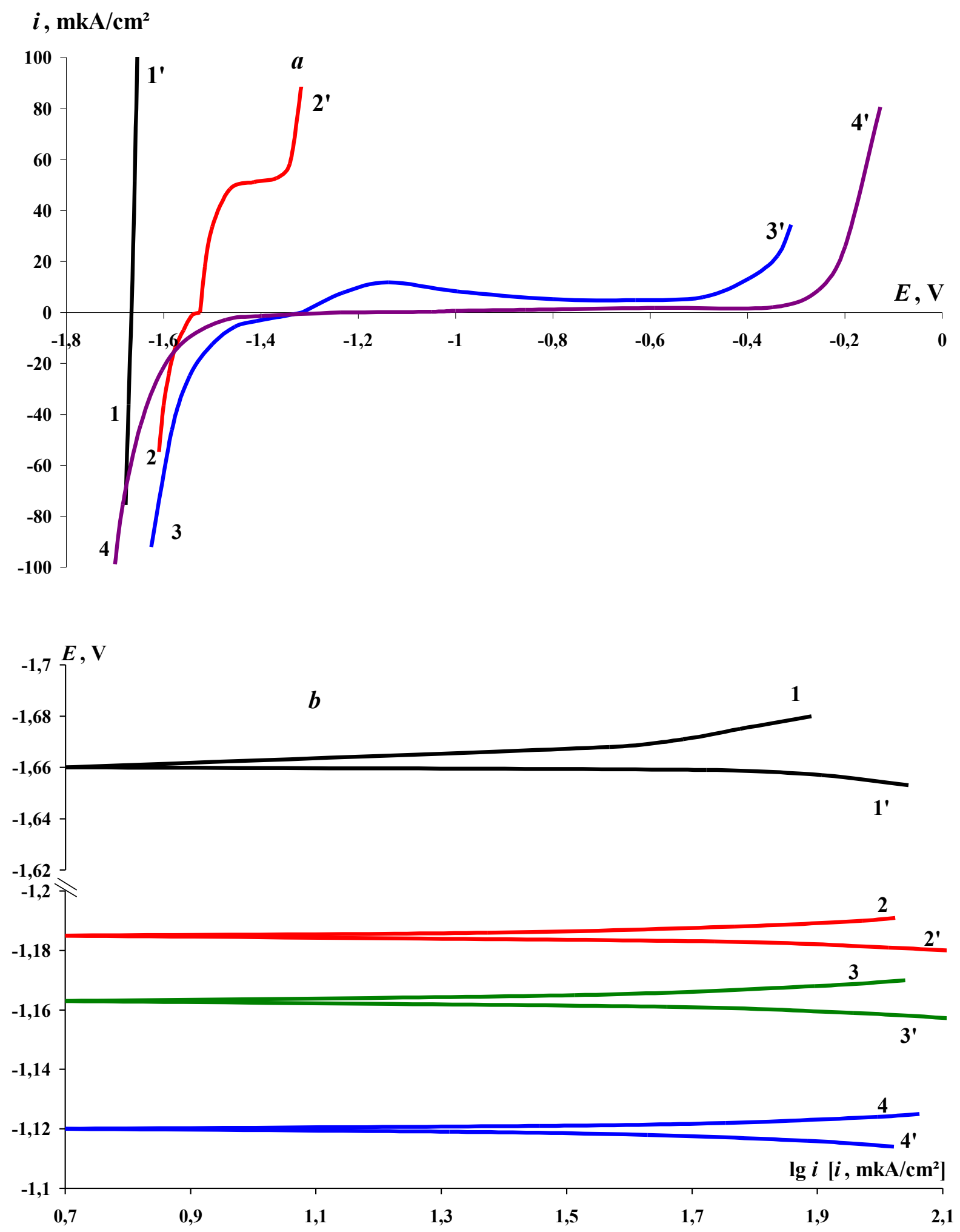

Figure 2. Polarization curves of magnesium in borate buffer with $\mathrm{pH} 7.4$ without (1) and with addition of $a$ ) potassium dichromate $\left.\left(2-1.0 ; 3-5.0 ; 4-10 \mathrm{mmol} \cdot \mathrm{L}^{-1}\right) ; b\right)$ sodium molybdate (2-1.0 mM; 3- $5 \mathrm{mM} ; 4-10 \mathrm{mM})$. 
It could be assumed that sodium molybdate, which increases the potential of $\mathrm{Mg}$ even more considerably (Figure 1a), would reduce the rate of electrode reactions similarly to chromate. However, this is not confirmed by polarization measurements (Figure 2b): no significant changes in $\mathrm{Mg}$ polarization upon potential shift both in the cathodic and anodic region are observed, whereas the increase in $E_{\mathrm{c}}$ is only due to molybdate reduction, i.e., its oxidizing properties that presumably lead to acceleration of the overall cathodic reaction. This can cause stimulation rather than inhibition of metal corrosion, as corrosion tests confirm (Table 1).

Table 1. Results of corrosion tests of magnesium in borate buffer solution containing corrosion inhibitors.

\begin{tabular}{llrcc}
\hline No. & \multicolumn{2}{c}{ Solution composition } & $\boldsymbol{K}, \mathbf{g} \cdot\left(\mathbf{m}^{\mathbf{2}} \cdot \mathbf{h}\right)^{-\mathbf{1}}$ & $\boldsymbol{Z}(\mathbf{\%})$ \\
\hline \multicolumn{4}{c}{ Test duration = 1 hour } \\
\hline 1 & Borate buffer solution (pH 7.4) & & 6.20 & - \\
2 & same + sodium molybdate & $1 \mathrm{mM}$ & 8.48 & -36.7 \\
3 & & $5 \mathrm{mM}$ & 7.98 & -28.7 \\
4 & $10 \mathrm{mM}$ & 7.06 & -13.8 \\
5 & same + 1,2,4-triazole & $10 \mathrm{mM}$ & 6.28 & -1.2 \\
6 & & $30 \mathrm{mM}$ & 5.89 & 5.0 \\
7 & same + 1,2,3-benzotriazole & $10 \mathrm{mM}$ & 6.08 & 1.9 \\
8 & same + 5-chlorobenzotriazole & $10 \mathrm{mM}$ & 3.48 & 43.9 \\
9 & same + 1 mM DOPh + 1.0 mM IFKhAN-92 & 0.14 & 97.7 \\
10 & Borate buffer solution (pH 9.2) & & 3.91 & - \\
11 & same + 5-chlorobenzotriazole & $1.0 \mathrm{mM}$ & 1.70 & 56.5 \\
12 & & $5.0 \mathrm{mM}$ & 0.87 & 77.7 \\
13 & & $10.0 \mathrm{mM}$ & 0.38 & 90.3 \\
14 & same + 10.0 mM 1,2,4-triazole & & 4.39 & -12.3 \\
15 & same + 10.0 mM 1,2,3-benzotriazole & 4.26 & -8.9 \\
\hline
\end{tabular}

On the other hand, as mentioned above, corrosion inhibition of $\mathrm{Mg}$ alloys was also observed upon surface treatment or incorporation of organic compounds into the coating. Of these compounds, various triazoles are noteworthy that are still little studied for protection of $\mathrm{Mg}$ and its alloys. According to [11], TA proved to be an efficient corrosion inhibitor for $\mathrm{Mg}$ alloy $\mathrm{AZ3} 1$ containing 3\% $\mathrm{Al}$ and $1 \% \mathrm{Zn}$, therefore it was interesting to study this compound and its derivatives as corrosion inhibitors of $\mathrm{Mg}$ in a neutral aqueous solution. 
In the solutions containing $10 \mathrm{mmol} / 1$ of the triazoles being studied, $E_{\mathrm{s}}$ is less negative than in pure borate buffer and also increases with time (Figure 1b). In the case of additives such as TA, BTA or Cl-BTA, $E_{\mathrm{f}}$ of magnesium becomes by $20-30 \mathrm{mV}$ more positive than in the background solution. However, a particularly noticeable increase to $E_{\mathrm{s}}=-1.60$ occurs in a solution containing IFKhAN-92. Although in all the solutions studied the potential of $\mathrm{Mg}$ increases with time, the established $E_{\mathrm{f}}$ value in pure borate buffer is less negative than in the presence of organic additives. Only in the BTA solution, $E$ remains more positive than in the background solution for 2 hours, but it is still established at the same value $E_{\mathrm{f}}=-1.40 \mathrm{~V}$. It is important that the most negative $E_{\mathrm{f}}$ is found in solutions of substituted triazoles with considerable hydrophobicity, i.e., Cl-BTA and IFKhAN-92. ${ }^{1}$ (For individual compounds, i.e., all the additives studied except IFKhAN-92, the criterion of hydrophobicity is considered to equal the logarithm of the partition coefficient $(\log P)$ of the compound of interest in two immiscible liquids, octanol-water, or $\log D$ with adjustment for acid dissociation [20]. For example, the $\log P$ value in the series TA - BTA - Cl-BTA increases from hydrophilic TA to the most hydrophobic Cl-BTA: $-0.58,1.34$ and 2.10 .

The anodic polarization curves of $\mathrm{Mg}$ in borate buffer containing various $C_{\mathrm{TA}}$ almost do not differ from those obtained in the absence of a triazole, which indicates that this triazole poorly inhibits the metal dissolution (Figure 3a). This confirms the results of the corrosion tests carried out at $C_{\mathrm{TA}}=10$ and $30 \mathrm{mmol} / \mathrm{l}$ (Table 1). It is possible that the hydrophilic TA can provide a good level of protection of technical $\mathrm{Mg}$, similar to that observed for $\mathrm{Mg}$ alloys in [10], but at higher $C_{\mathrm{TA}}$. However, preference should clearly be given to the more hydrophobic Cl-BTA, which significantly increases the anodic polarization of the electrode (Figure 3b). It increases $Z$ by more than an order at the same $C$ as TA (Table 1). It is also more efficient than BTA, which may be due not only to its higher hydrophobicity. Another reason is the increase in acidity in the series TA ( $\left.\mathrm{p} K_{\mathrm{a}} 10.0\right)$ $<$ BTA $\left(\mathrm{p} K_{\mathrm{a}} 8.38\right)<$ Cl-BTA $\left(\mathrm{p} K_{\mathrm{a}} 5.46\right)$, because as $\mathrm{pK}_{\mathrm{a}}$ of NH-acids decreases, their dissociation is facilitated and the amount of triazolate anions in solution increases. If the surface of the metal being protected is positively charged, then anions are adsorbed more readily than neutral organic molecules. Therefore, their inhibitive properties may increase upon transition from neutral to slightly alkaline solution. Indeed, upon increasing the $\mathrm{pH}$ of borate solution from 7.36 to 9.20 , its corrosivity with respect to $\mathrm{Mg}$ decreases by $37 \%$, but the degree of protection of 1.0 and $10 \mathrm{mM} \mathrm{Cl-BTA}$ increases from 3.95 and $47.0 \%$ to 56.5 and $90.0 \%$, respectively (Table 1). Unfortunately, such an increase in the $\mathrm{pH}$ of borate solution, which has such a beneficial effect on the inhibitive properties of Cl-BTA, at least at $C=10 \mathrm{mM}$, fails to provide protective properties to TA or BTA.

\footnotetext{
${ }^{1}$ This is evidenced by the fact that due to low solubility in water, they were injected into the buffer solution in the form of a solution in isopropanol. The addition of the same amount of isopropanol $(\leq 10 \%)$ little affected the corrosion-electrochemical behavior of $\mathrm{Mg}$.
} 

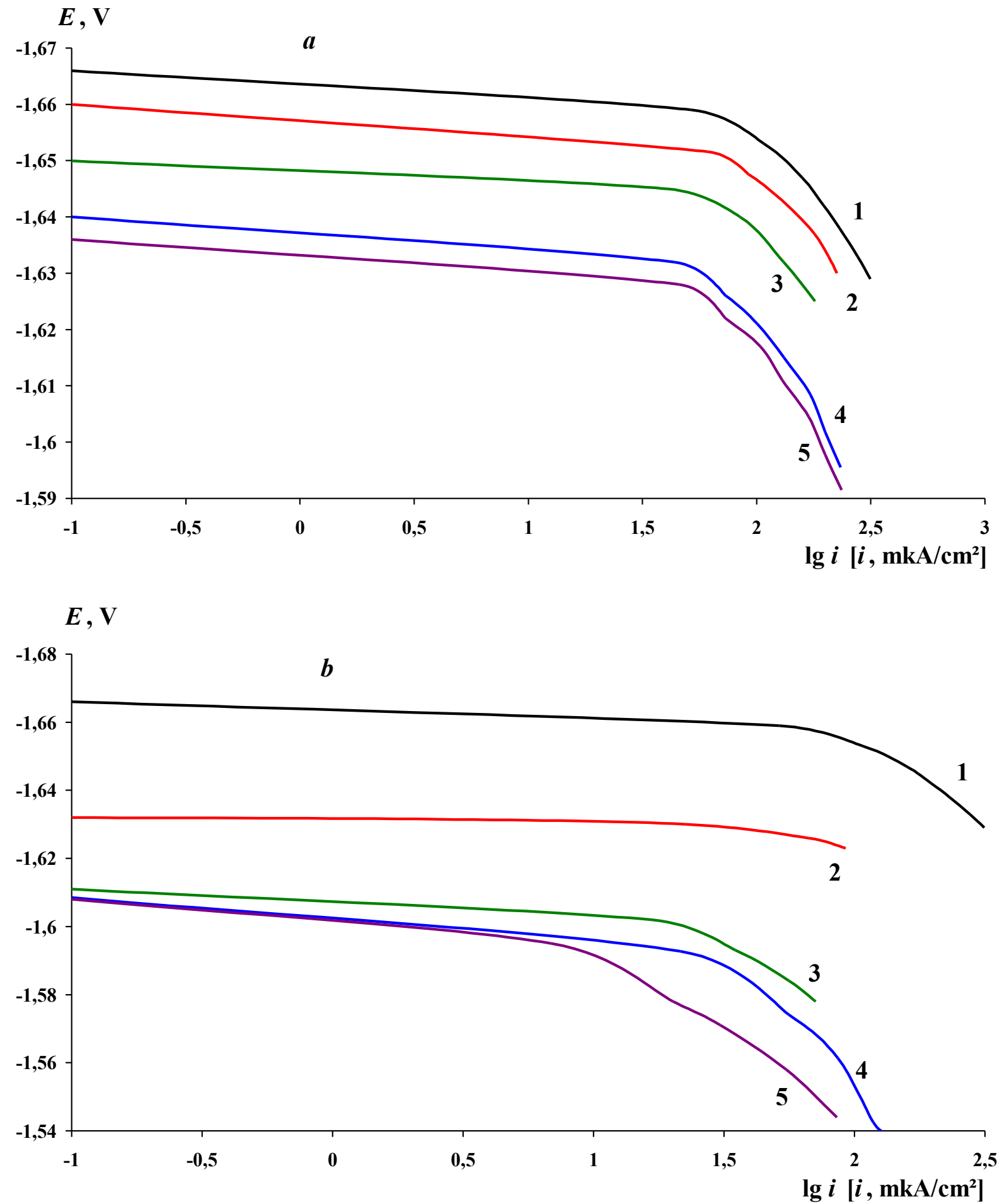

Figure 3. Polarization curves of magnesium in borate buffer with $\mathrm{pH} 7.4$ without (1) and with addition of TA $(a)$ and Cl-BTA $(b), \mathrm{mmol} \cdot \mathrm{L}^{-1}: 2-1.0 ; 3-5.0 ; 4-10.0 ; 5-25.0$. 
In neutral solution, IFKhAN-92 inhibitor, which is a mixture of triazole derivatives, is the most efficient in $\mathrm{Mg}$ protection. It proved itself as a good inhibitor of steel corrosion and hydrogen absorption in highly corrosive $\mathrm{H}_{2} \mathrm{~S}$-containing environments and solutions of various acids [21-23]. As expected, IFKhAN-92 can significantly increase not only anodic but also cathodic electrode polarization and, although it requires its relatively high $C \geq 10 \mathrm{mmol} / 1$ (Figure 4). Corrosion tests proved that with IFKhAN-92, $Z=74.7-75.5 \%$ can be reached in neutral solution, but higher protection is prevented by limited water solubility of the inhibitor, even with its improvement by $10 \%$ isopropanol addition (Figure 5a). In this context, of interest are data obtained in weakly alkaline borate solution, where $Z$ can be raised to $90 \%$ at $C=10 \mathrm{mM}$ (Figure 5b). For smaller $C=1.0$ and $5.0 \mathrm{mM}$, though it is somewhat less efficient than Cl-BTA, but it can still significantly reduce the rate of $\mathrm{Mg}$ corrosion. However, an increase in $C$ to 15 or $20 \mathrm{mM}$ decreases $Z$ somewhat, to 83.6 and $80.8 \%$, respectively, though it is still higher than the best results in neutral borate solution.

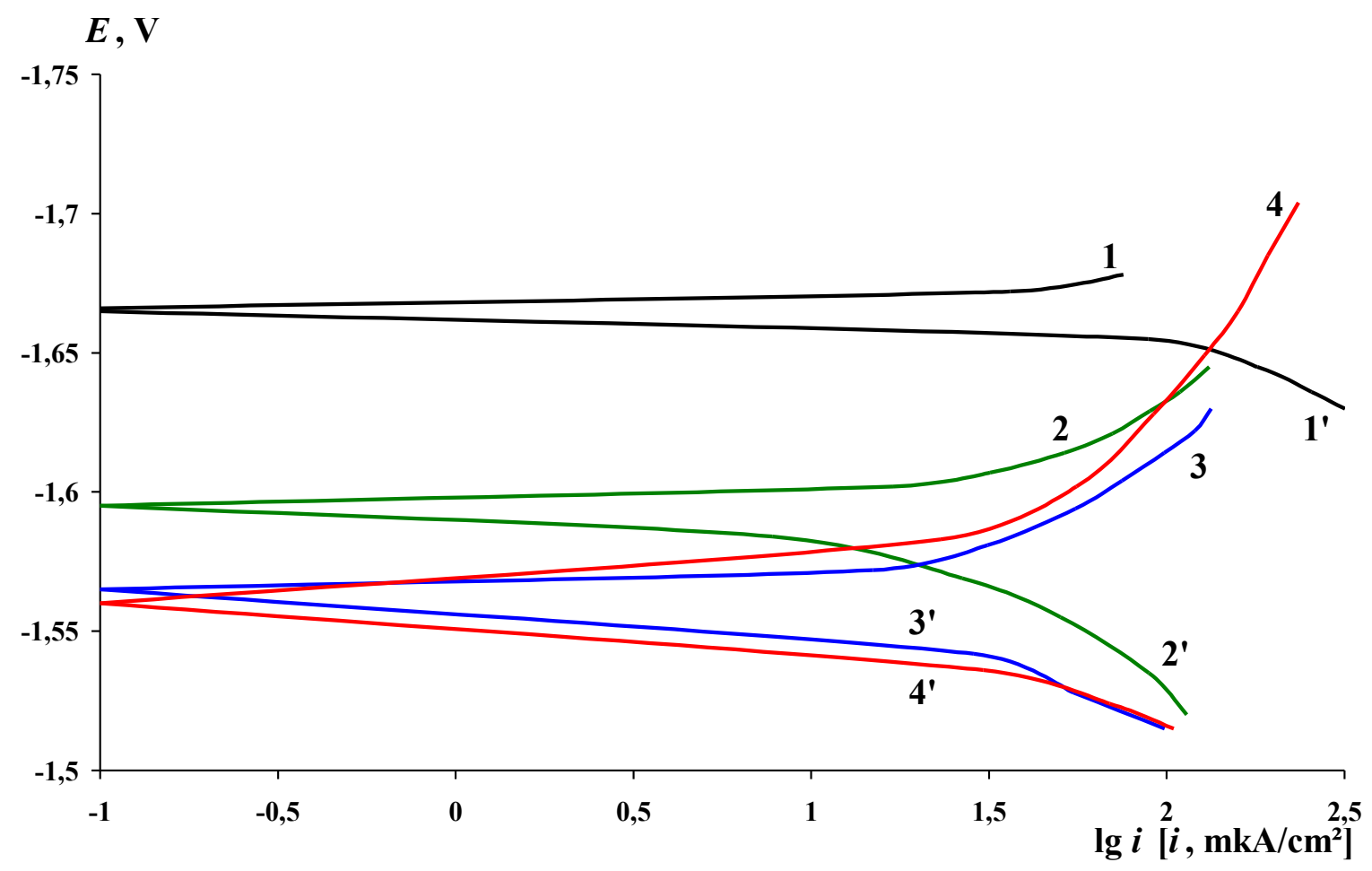

Figure 4. Cathodic $(1-4)$ and anodic $\left(1^{\prime}-4^{\prime}\right)$ polarization curves of magnesium in borate buffer with $\mathrm{pH} 7.4$ without $\left(1,1^{\prime}\right)$ and with addition of IFKhAN-92 $\left(\mathrm{mmol} \cdot \mathrm{L}^{-1}\right): 2-1.0 ; 3-$ $10.0 ; 4-25.0$. 

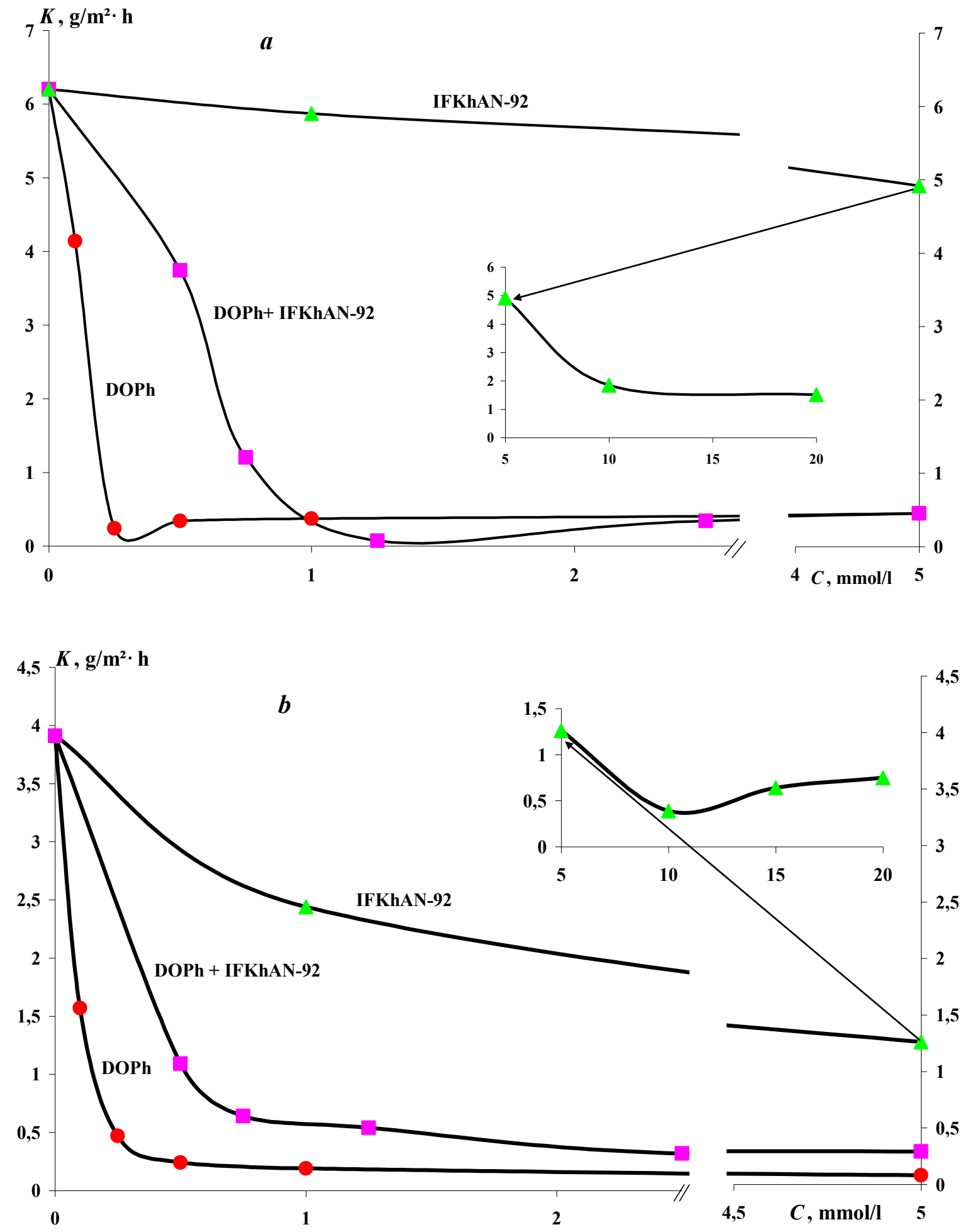

Figure 5. Dependence of magnesium corrosion rate in borate solution with $\mathrm{pH} 7.4(a)$ and 9.2 (b) on the concentration of DOPh (1), IFKhAN-92 (2) and an IFKhAN-92 + DOPh mixture (1:4). 


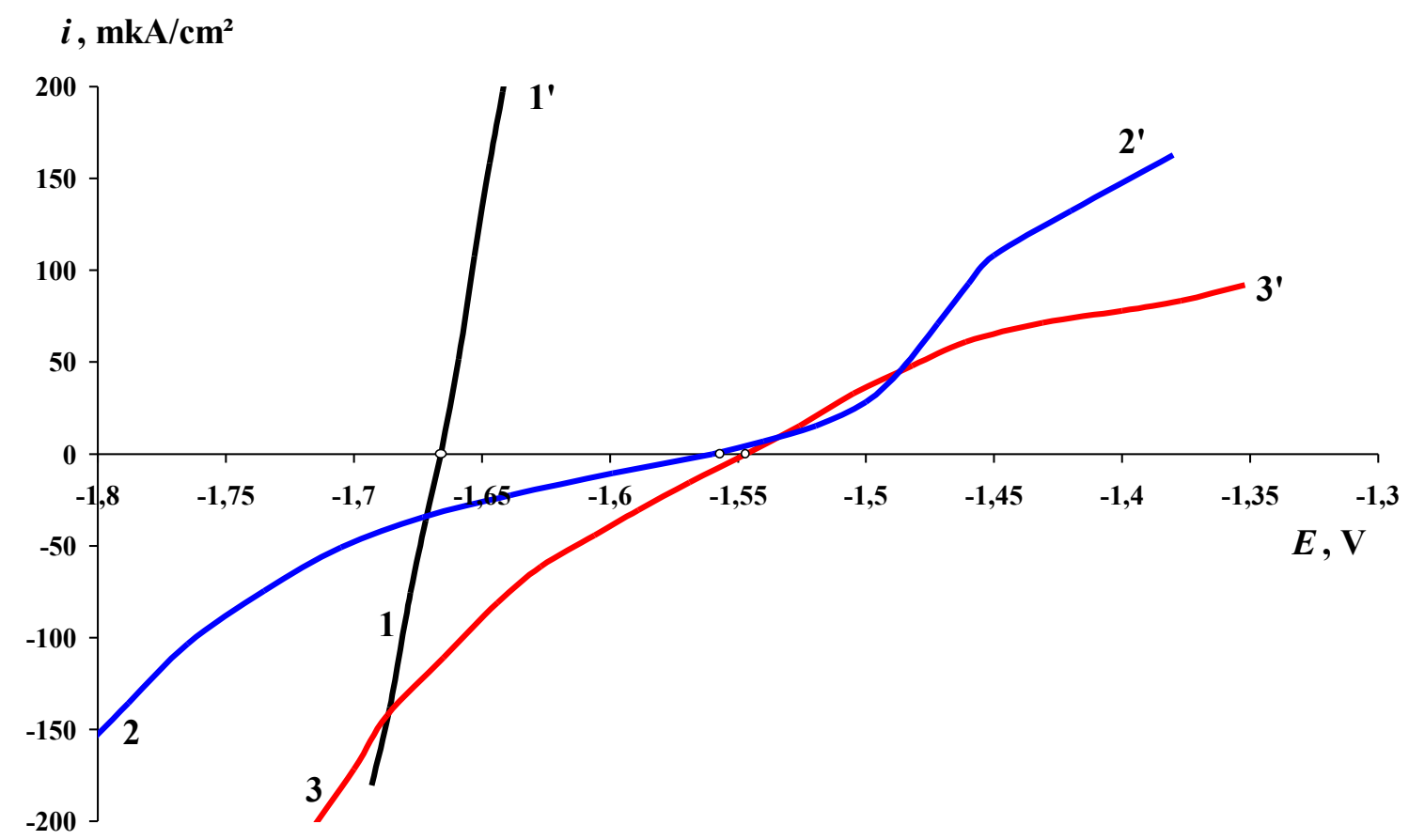

Figure 6. Polarization curves of magnesium in borate buffer solution with $\mathrm{pH} 7.4$ without (1) and with addition of DOPh $\left(\mathrm{mmol} \cdot \mathrm{L}^{-1}\right): 2-1.0 ; 3-5.0$.

It seemed worthwhile to explore yet another approach for increasing the protective properties of the best inhibitors - triazole derivatives. It can be done using IFKhAN-92 together with small additions of an anion-active metal corrosion inhibitor such as sodium dioctyl phosphate $(\mathrm{DOPh})$ that has high adsorption and passivation ability on some metals $[24,25]$. Indeed, even small amounts of DOPh can slow down not only the anodic dissolution of $\mathrm{Mg}$ but also the cathodic reaction on its surface (Figure 5). It is interesting that at low $C_{\mathrm{DOPh}}=1.0 \mathrm{mmol} / \mathrm{l}$ its inhibitive effect on the cathodic reaction is stronger, but decreases markedly with a concentration increase. It is possible that under such negative $E$, the DOPh anion can undergo reduction, just as it was observed with inorganic phosphate ions on zinc $[26,27]$. Their reduction to phosphites was confirmed not only in slightly acidic and neutral solutions at $E \leq-0.86 \mathrm{~V}$, but also in alkaline media at $E \leq-0.97$ [27].

Corrosion tests have demonstrated the high efficiency of small DOPh amounts and their ability to increase the protection of $\mathrm{Mg}$ to even greater values when combined with IFKhAN-92 (Figure 6a). It is characteristic that at the ratio DOPh:IFKhAN-92 $=1: 4$, the consumption of the substituted triazole decreases abruptly and $Z_{\text {mix }}$ increases compared to $Z_{\text {DOPh }}$ at the same $C$. In weakly alkaline medium, this was observed only at low $C_{\mathrm{DOPh}}$ $<0.25 \mathrm{mM}$, whereas with $C_{\mathrm{DOPh}}$ increase, DOPh became more efficient than the mixture (Figure $6 \mathrm{~b}$ ). On the other hand, the advantage of the mixture over any of its components in neutral buffer is also observed with an increase in the fraction of DOPh. In fact, $Z$ at $C=$ $1.0 \mathrm{mM}$ is $94 \%$ for DOPh, $3.5 \%$ for IFKhAN-92, and a $97.7 \%$ for their mixture. The latter value is higher than even that of $5 \mathrm{mM} \mathrm{DOPh}(Z=92.7 \%)$. 
An important feature of the action of the inhibitors studied on the corrosion of $\mathrm{Mg}$ is that $Z$ changes in time (Table 2). In the pure buffer with $\mathrm{pH} 7.36$, the corrosion rate passes through a small maximum, i.e., it increases in the time range from 0.5 to 4.0 hours, which is probably due to destruction of the oxide layer formed in the air, and then decreases due to the protective properties of the resulting gray-colored film of corrosion products. After 12.0 hours it apparently reaches a constant value of $K=5.53 \pm 0.02 \mathrm{~g} / \mathrm{m}^{2} \mathrm{~h}$. Addition of a small $C_{\text {IFKhAN-92 }}$ amount slightly reduces the corrosion rate, but its dependence on the test time is little different from that of the original buffer. An even smaller amount of DOPh efficiently reduces the corrosion rate, but its inhibitory effect changes in time in a different way: it slowly decreases initially and then decreases abruptly. It is essential that the abrupt decrease in the protective effect of DOPh cannot be explained by the fact that $C_{\mathrm{DOPh}}$ is just small and insufficient to block the entire metal surface. This is indicated by the fact that the growth of $C_{\mathrm{DOPh}}>0.25 \mathrm{mM}$ itself (at the same test time) does not increase but reduces the $Z$ of the inhibitor (Figure 6). It can be assumed that $\mathrm{DOPh}$, like organic complex formers that are capable of forming water-soluble compounds with cations of a metal being protected as their content in solution increases, prevents the formation of a protective hydroxide-oxide film on $\mathrm{Mg}$ [28]. It is therefore that small $C_{\mathrm{DOPh}}$ amounts can be promising for improvement of protective action of IFKhAN-92 with respect to $\mathrm{Mg}$. Indeed, the formulation of $0.25 \mathrm{mmol} / 1 \mathrm{DOPh}$ with $1.0 \mathrm{mmol} / 1 \mathrm{IFKhAN}-92$ demonstrates particularly high protective properties in the first 4.0 hours, exceeding 2.6-3.4 fold DOPh itself at its optimal concentration. However, an increase in not only $C_{\mathrm{DOPh}}$ but also $\mathrm{C}_{\mathrm{IFKhAN}-92}$ in this formulation significantly degrades the inhibitor efficiency, apparently due to competition of inhibitor adsorption with formation of an oxide-hydroxide film. This is in good agreement

Table 2. Results of corrosion tests of magnesium in borate buffer solution with $\mathrm{pH} 7.36$ containing corrosion inhibitors.

\begin{tabular}{|c|c|c|c|c|}
\hline \multirow{2}{*}{ Solution composition $\left(\mathrm{mmol} \cdot \mathrm{L}^{-1}\right)$ : } & \multicolumn{4}{|c|}{$\begin{array}{c}\text { Corrosion rate of magnesium, } \mathbf{g} \cdot\left(\mathbf{m}^{2} \cdot \mathbf{h}\right)^{-1}, \\
\text { at test duration (hours): }\end{array}$} \\
\hline & 0.5 & 1.0 & 4.0 & 12.0 \\
\hline Borate buffer & 5.60 & 6.20 & 5.74 & 5.51 \\
\hline same +1.0 mM IFKhAN-92 & 5.30 & 5.88 & 5.34 & 5.24 \\
\hline same $+0.25 \mathrm{mM} \mathrm{DOPh}$ & 0.18 & 0.24 & 0.31 & 1.88 \\
\hline \multicolumn{5}{|l|}{ same $+0.25 \mathrm{mM} \mathrm{DOPh}+$ IFKhAN-92 } \\
\hline $1.0 \mathrm{mM}$ & 0.06 & 0.07 & 0.12 & 1.67 \\
\hline $4.0 \mathrm{mM}$ & - & 0.27 & - & 2.95 \\
\hline \multicolumn{5}{|l|}{ same $+1.0 \mathrm{mM}$ DOPh + IFKhAN-92 } \\
\hline $1.0 \mathrm{mM}$ & - & 0.14 & 0.15 & 2.83 \\
\hline $4.0 \mathrm{mM}$ & - & 0.45 & 0.76 & 2.43 \\
\hline
\end{tabular}


with the fact that even at the optimum ratio of inhibitor components, a high degree of protection can only be achieved for short-term exposures of $\mathrm{Mg}$ in neutral solution and at relatively low inhibitor concentration. In fact, in case of exposure for 1 hour in neutral solution, the most efficient composition $(0.25 \mathrm{mM} \mathrm{DOPh}+1.0 \mathrm{mM}$ IFKhAN-92) provides $Z=98.8 \%$, but after 12 hours, this value is reduced to $69.7 \%$.

In a slightly alkaline solution, the protective effect of the mixed inhibitor changes considerably. In a solution with $\mathrm{pH} 9.2$, the best protection of $\mathrm{Mg}$ is achieved at a higher overall $C_{\text {in }}(1.5 \mathrm{mM} \mathrm{DOPh}+6.0 \mathrm{mM}$ IFKhAN-92) than in the neutral solution, but the $Z$ value decreases with time more slowly (from 95.4 in a $1 \mathrm{~h}$ test to only $92.9 \%$ in a $12 \mathrm{~h}$ test, whereas in the solution with $\mathrm{pH} 7.4$ at the same $C_{\mathrm{in}}, Z$ decreases from 92.6 to $82.6 \%$ ). Therefore, $\mathrm{Mg}$ passivation was performed in aqueous solutions (in the absence of borate) with $C_{\text {in }}=5.0-7.5 \mathrm{mM}$ at various $\mathrm{pH}$ and $t$ values (Figure 7).

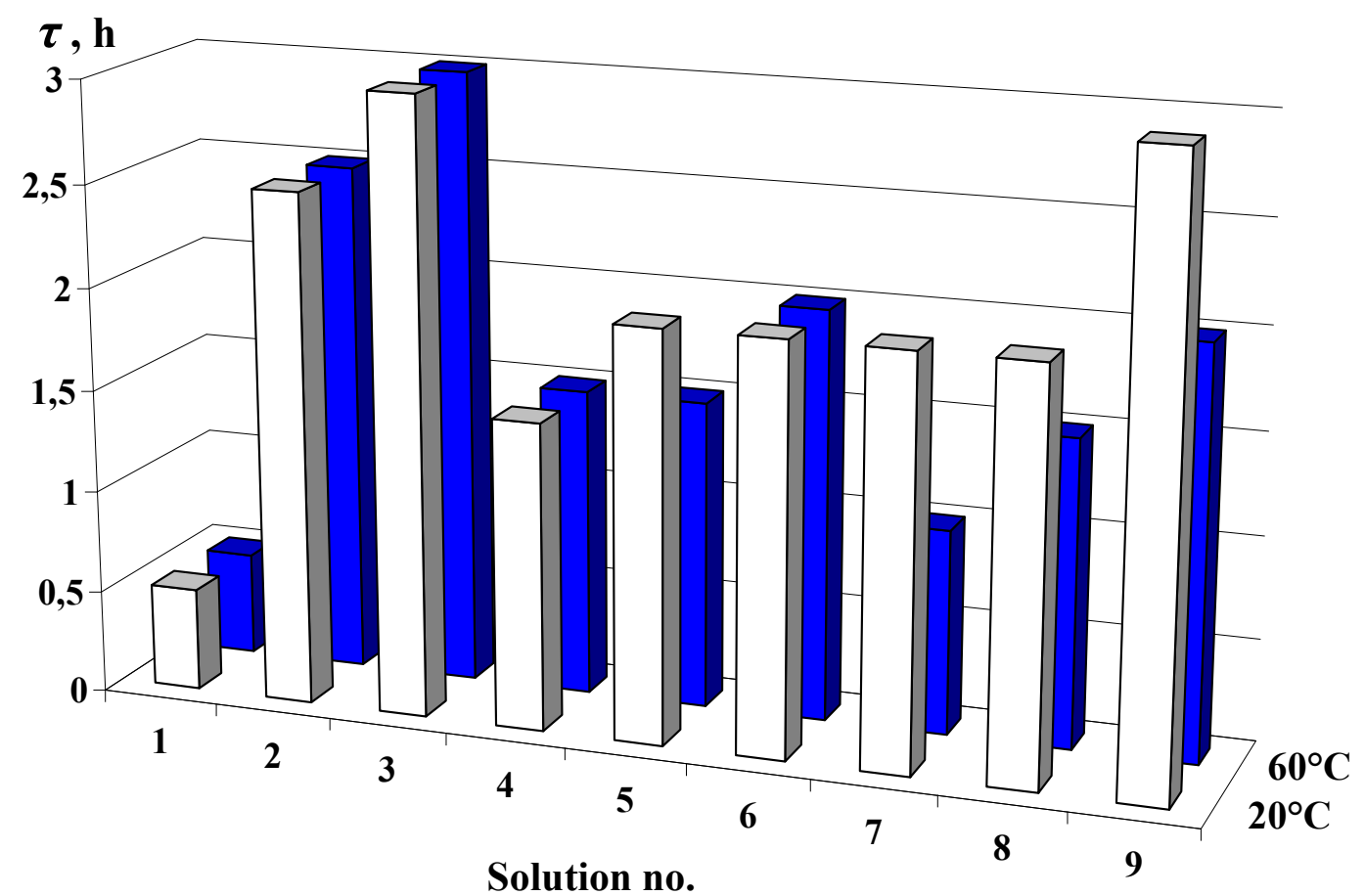

Figure 7. Dependence of the time to appearance of the first corrosion damage $(\tau)$ on magnesium specimens placed into a heat and moisture chamber without (1) and with pretreatment (2-9) in aqueous solutions with $t=20$ or $60^{\circ} \mathrm{C}$ and with corrosion inhibitors, $C_{\text {inh }}=$ $5 \mathrm{mM}: 2$ - potassium dichromate $(\mathrm{pH} 4.4) ; 3$ - potassium dichromate $(\mathrm{pH} 9.2) ; 4-\mathrm{DOPh}(\mathrm{pH}$ 7.2); 5 - DOPh (pH 9.2); 6 - DOPh + IFKhAN-92 (1:4, pH 6.9); 7 - DOPh + IFKhAN-92 (1:4, $\mathrm{pH} 9.2)$. The composition used in variants 8 and 9 contained $2.0 \mathrm{mM} \mathrm{DOPh}+8 \mathrm{mM}$ IFKhAN-92, without and with stirring of the passivating solution, respectively.

In the absence of passivating treatment, corrosion spots appear on magnesium samples placed in a $100 \%$ relative humidity chamber after 30 minutes and rapidly increase with time. Treatment of $\mathrm{Mg}$ in a neutral $5 \mathrm{mM}$ DOPh solution, regardless of treatment 
time, protects it from corrosion for $\tau=1.5 \mathrm{~h}$. Treatment in the same solution with $\mathrm{pH} 9.2$ at room temperature increased $\tau$ to 2 hours, however, an increase in $t$ impaired $\mathrm{Mg}$ protection.

Chromate treatment in an acidic solution ( $\mathrm{pH} 4.4)$, irrespective of treatment duration, provides $\mathrm{Mg}$ stability for 2.5 hours, and in slightly alkaline solution - for 3.0 hours. Passivating treatment of $\mathrm{Mg}$, both in neutral and in slightly alkaline solution of the mixed inhibitor (1.0 mM DOPh $+4.0 \mathrm{mM}$ IFKhAN-92), provides the best protection at $t=20^{\circ} \mathrm{C}$ $(\tau=2.0 \mathrm{~h})$. It is superior in efficiency to similar treatment with a DOPh solution but inferior to chromate treatment carried out not only in a weakly alkaline but also in an acidic acidic solution. Also, protection cannot be improved by increasing $C_{\text {mix }}$ twofold, but the effect of chromate treatment can be achieved by mixing this slightly alkaline solution (Figure 7). Solution stirring that does not affect the efficiency of chromate passivation increases it slightly for DOPh $(\tau=2.0 \mathrm{~h})$, therefore the protective effect of its mixture with IFKhAN-92 is also improved.

To enhance the passivating effect of inhibitors, it is possible to use a small addition of trialkoxysilane (TAS), though it by itself may fail to provide inhibitive properties with respect to the metal to be protected. Chemical reactions of TAS lead to the formation of poorly soluble siloxane nano-sized layers on the surface of the metal that can increase the stability of inhibitor adsorption films. In this case (Figure 8), replacement of $4 \mathrm{mM} \mathrm{DOPh}$ by an equimolar amount of TAS did not change the efficiency of $\mathrm{Mg}$ treatment at room temperature but increased it slightly at elevated temperature (up to $\tau=2.0 \mathrm{~h}$ ). It proved to be enough to add as little as $1 \mathrm{mM}$ TAS to a non-stirred solution of the mixed inhibitor (5.0 $\mathrm{mM})$ with $\mathrm{pH} 9.2$ to increase $\tau$ to 2.5 hours $\left(t=20^{\circ} \mathrm{C}\right)$ or 3.0 hours $\left(t=60^{\circ} \mathrm{C}\right)$. Increasing $C_{\text {TAS }}$ to $5.0 \mathrm{mM}$ makes the efficiency of $\mathrm{Mg}$ passivation treatment with the mixed inhibitor $\left(t=20^{\circ} \mathrm{C}, \tau=3.5 \mathrm{~h}\right)$ higher than that obtained using chromate solutions.

A combination of stirring and optimal temperature, $\mathrm{pH}$ and $C$ of the mixed inhibitor in the passivating solution with an addition of TAS to it can improve Mg protection with ultrathin organic coating formed under drastic humid atmosphere conditions. Comparison of the results shown in Figures 7,8 and Table 3 shows that in the case of a threecomponent inhibitor, its stirred solutions generally either do not impair or do improve the stability of protective layers. This beneficial effect of $C_{\mathrm{TAS}}$ is optimal at $5.0 \mathrm{mM}$, which provides $\tau=4.0-4.5$ hours, i.e., it extends the induction period of $\mathrm{Mg}$ corrosion under drastic conditions 8-9 fold. This allows one to hope that further studies aimed at optimizing Mg passivation techniques will make it possible to develop an environmentally friendly technology for protection of this metal and its alloys from atmospheric corrosion with thin and ultrathin organic coatings. 


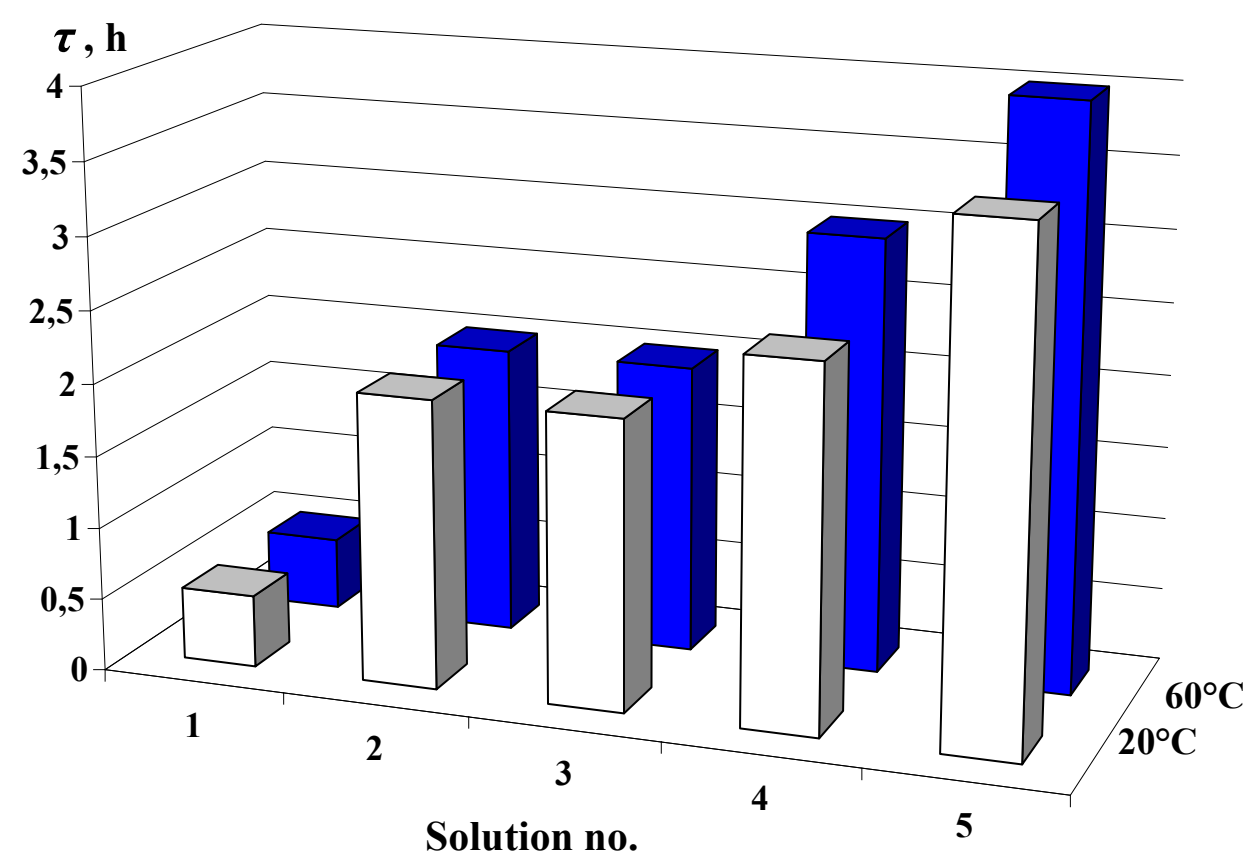

Figure 8. Dependence of the time to appearance of the first corrosion damage $(\tau)$ on magnesium specimens placed into a heat and moisture chamber without (1) and with pre-treatment (2-9) in aqueous solutions with $t=20$ or $60^{\circ} \mathrm{C}$ at $\mathrm{pH} 9.2: 2-5.0 \mathrm{mM} \mathrm{DOPh} ; 3-1.0 \mathrm{mM} \mathrm{DOPh}+4 \mathrm{mM}$ TAS; $4-1.0 \mathrm{mM}$ DOPh + $4 \mathrm{mM}$ IFKhAN-92 + 1.0 mM TAS; $5-1.0 \mathrm{mM} \mathrm{DOPh}+4 \mathrm{mM}$ IFKhAN-92 + 5.0 mM TAS.

Table 3. Corrosion results in a heat and moisture chamber for magnesium samples the pre-treated in aqueous solutions of corrosion inhibitors stirred at $V=0.3 \mathrm{~m} \cdot \mathrm{s}^{-1}$.

\begin{tabular}{ccccc}
\hline No. & Passivation solution composition & pH & $\begin{array}{c}\text { Treatment } \\
\text { temperature, } \\
{ }^{\circ} \mathbf{C}\end{array}$ & $\begin{array}{c}\boldsymbol{\tau} \text { until the } \\
\text { first corrosion } \\
\text { damage, h }\end{array}$ \\
\hline 1 & without an inhibitor (no treatment) & - & - & 0.5 \\
2 & $5.0 \mathrm{mM} \mathrm{DOPh}$ & 9.2 & 60 & 2.0 \\
3 & $5.0 \mathrm{mM} \mathrm{K} \mathrm{CrO}_{4}$ & 9.2 & 60 & 3.0 \\
4 & $1.0 \mathrm{mM} \mathrm{DOPh}+4.0 \mathrm{mM}$ IFKhAN-92 & 7.4 & 60 & 2.0 \\
5 & same as above & 9.2 & 20 & 2.5 \\
6 & $1.0 \mathrm{mM} \mathrm{DOPh}+4.0 \mathrm{mM}$ IFKhAN-92+1.0 mM TAS & 9.2 & 60 & 3.0 \\
7 & $1.0 \mathrm{mM} \mathrm{DOPh}+4.0 \mathrm{mM}$ IFKhAN-92+5.0 mM TAS & 7.4 & 60 & 2.5 \\
8 & same as above & 9.2 & 20 & 3.5 \\
9 & same as above & 9.2 & 60 & 4.0 \\
10 & $1.0 \mathrm{mM} \mathrm{DOPh}+4.0 \mathrm{mM}$ IFKhAN-92+10.0 mM TAS & 9.2 & 60 & 3.0 \\
11 & $1.0 \mathrm{mM} \mathrm{DOPh}+4.0 \mathrm{mM}$ IFKhAN-92+20.0 mM TAS & 9.2 & 60 & 2.5 \\
\hline
\end{tabular}




\section{Conclusions}

1. Unlike chromate, another inorganic corrosion inhibitor, sodium molybdate, shows no passivating properties with respect to $\mathrm{Mg}$ in neutral solution. Moreover, at concentrations $C_{\text {in }} \leq 0.01 \mathrm{M}$ it only stimulates magnesium corrosion in borate buffer with $\mathrm{pH} 7.4$.

2. 1,2,4-Triazole and BTA very slightly slow down $\mathrm{Mg}$ dissolution in neutral solution. However, their derivatives (5-chloro-BTA or a mixture of substituted triazoles IFKhAN-92) inhibit the corrosion of $\mathrm{Mg}$, although they do not passivate it. Not only the increase in hydrophobicity, but also a decrease in $\mathrm{p} K_{\mathrm{a}}$ of these $\mathrm{NH}$-acids make a positive contribution to improving the protection of $\mathrm{Mg}$ by triazoles. Their efficiency increases in a solution with $\mathrm{pH} 9.2$ where the degree of protection $(Z)$ reaches $90 \%$, indicating the superiority of triazolate anions over the molecules of the same inhibitors.

3. In neutral solution, protection by dioctyl phosphate $(\mathrm{DOPh})$ is more efficient, but the dependences of $Z$ on $C_{\text {in }}$ or test duration for this compound have distinct maxima, similarly to triazoles. A possible reason for this is competition between the inhibitor adsorption and the growth of an oxide-hydroxide layer on $\mathrm{Mg}$.

4. Small additions of DOPh to IFKhAN-92 inhibitor increase the degree of magnesium protection. At the ratio of the components DOPh:IFKhAN-92 =1:4, not only the triazole consumption in neutral solutions decreases, but also $Z_{\text {mix }}$ increases compared to $Z$ of $\mathrm{DOPh}$ at the same concentration.

5. In the solution with $\mathrm{pH} \mathrm{9.2,} \mathrm{the} \mathrm{best} \mathrm{protection} \mathrm{of} \mathrm{Mg}$ is achieved at a higher total $C_{\text {in }}$ $(1.5 \mathrm{mM}$ DOPh $+6.0 \mathrm{mM}$ IFKhAN-92) than in neutral solution, but the magnitude of $Z$ decreases slowly with time. Therefore, it is not surprising that passivation treatment of $\mathrm{Mg}$ in order to impart stability in humid atmosphere is often more efficient in this solution than in neutral solution.

6. A combination of stirring and optimization of temperature, $\mathrm{pH}$ and the concentration of the mixed inhibitor in the passivating solution with addition of TAS can improve $\mathrm{Mg}$ protection by ultrathin organic coatings formed under conditions of drastic humid atmosphere and abundant water condensation. This treatment increases the time until the first corrosion damage on $\mathrm{Mg}$ in 8-9 fold.

\section{References}

1. I.D. Hanowalt, C.E. Nelson and I.A. Peloube, Metal Technol., 1941, 8, no. 6, 1.

2. Corrosion Volume I Metal/Environment Reactions, Ed. L.L. Shreir, $3^{\text {rd }}$ Edn., 1993, pp. 4:98-4:115.

3. M.A. Timonova, Zashchita ot korrozii magnievykh splavov (Corrosion protection of magnesium alloys), 1977, Moscow, Metallurgiya (in Russian).

4. G.V. Akimov and I.L. Rozenfeld, in Issledovaniya $v$ oblasti elektrokhimicheskogo $i$ korrozionnogo povedeniya metallov $i$ splavov (Studies in electrochemical and corrosion behavior of metals and alloys), 1950, Moscow, Oborongiz, pp. 201-233. 
5. J. Zhang and C. Wu, Recent Patents on Corrosion Sci., 2010, 2, 55.

6. J.E. Gray and B. Luan, J. Alloy Compd., 2002, no. 336, 88.

7. A.S. Shatrov, Korroz.: mater., zashch., 2004, no. 10, 31.

8. S.V. Gnedenkov, S.L. Sinebryukhov and V.I. Sergienko, Kompozitsionnye mnogofunktsional'nye pokrytiya na metallakh $i$ splavakh, formiruemye plazmennym elektroliticheskim oksidirovaniem (Polyfunctional composite coatings on metals and alloys formed by plasma electrolytic oxidation), 2013, Vladivostok, Dal'nauka (in Russian).

9. M. Ger, K. Yang, Y. Sung, W. Hwu and Y. Liu, Method for treating magnesium alloy by chemical conversion, U.S. patent 6,755,918, 2004.

10. O.V. Karavaia, A.C. Bastos, M.L. Zheludkevich, M.G. Taryba, S.V. Lamaka and M.G.S. Ferreira, Electrochim. Acta, 2010, 55, 5401.

11. J. Lei, L. Li and F. Pan, in Magnesium Alloys - Corrosion and Surface Treatments, Ed. F. Czerwinski, 2011, InTech, pp. 47-64.

12. A. Frignani, V. Grassi, F. Zanotto and F. Zucchi, Corros. Sci., 2012, 63, 29.

13. H. Gao, Q. Li, Y. Dai, F. Luo and H.X. Zhang, Corros. Sci., 2010, 52, 1603.

14. J. Stary, The Solvent Extraction of Metal Chelates, Pergamon Press, New York, 1964.

15. Yu.I. Kuznetsov and N.P. Andreeva, Elektrokhimiya, 2012, no. 4, 487 (in Russian).

16. Yu.I. Kuznetsov, Korroz.: mater., zashch., 2013. no. 4, 26.

17. Yu. I. Kuznetsov and L. P. Kazansky, Russ. Chem. Rev., 2008, 77, no. 3, 219.

18. Yu. I. Kuznetsov, Int. J. Corros. Scale Inhib., 2012, 1, no. 1, 3. doi: 10.17675/23056894-2012-1-1-003-015

19. M.S. Vukasovich, in: Reviews on Corrosion Inhibitor Science and Technology, Eds. A.Raman and P. Labine, 1993, NACE, Houston, II-12-1.

20. C. Hansch and A. Leo, Substituent Constants for Correlation Analysis in Chemistry and Biology, New York, Wiley, 1981.

21. L.V. Frolova, Yu.I. Kuznetsov and O.O. Zel', Korroz.: mater., zashch., 2008, no. 1, 23 (in Russian).

22. L.V. Frolova, Yu.I. Kuznetsov and O.O. Zel', Korroz.: mater., zashch., 2012, no. 6, 14 (in Russian).

23. Ya.G. Avdeev, L.V. Frolova, Yu.I. Kuznetsov and O.O. Zel', Korroz.: mater., zashch., 2010, no. 5, 22 (in Russian).

24. Yu.I. Kuznetsov, N.P. Andreeva and G.Yu. Kazanskaya, Zashch. met. (Protection of Metals), 2000, 36. no. 4, 351 (in Russian). 
25. Yu.I. Kuznetsov, N.P. Andreeva, N.P. Sokolova and R.A. Bulgakova, Zashch. met. (Protection of Metals), 2001, 37, no. 6, 578 (in Russian).

26. Yu.N. Mikhailovsky and V.M. Popova, Zashch. met. (Protection of Metals), 1984, 20, no. 2, 204 (in Russian).

27. L.P. Podgornova, Yu.I. Kuznetsov and S.V. Gavrilova, Zashch. met. (Protection of Metals), 2003, 39, no. 3, 248 (in Russian).

28. Yu.I. Kuznetsov, Organic Inhibitors of Corrosion of Metals, 1996, New York, Plenum Press. 